\title{
Cognitive Behavioral Therapy of Exhibitionism
}

An article with a case from practice Jan Jokl

Kosmonosy Psychiatric Hospital, Department of Sexology jokljan@email.cz

ABSTRACT: Exhibitionism is one of the most common sexual deviations. The author of this article focuses primarily on the definition of exhibitionistic behavior itself and on the profile of the patient committing these sexual offenses, since understanding the compulsive behavior of an exhibitionist is the cornerstone of successful psychotherapy. In the second part, the article deals with the therapy of exhibitionism with a focus on cognitive behavioral procedures in individual, couple's and group psychotherapy.

Key words: Exhibitionism, CBT, Cognitive behavioral therapy, Exhibition, Stripping, Individual therapy, Couple's therapy, Group therapy, Intimacy Training, Strengthening of Self-confidence, Empathy training

\section{Introductory Case Report}

Man, O. T., 36 years old. Sexologically examined for the first time at 33 years in the court proceedings with the verdict of protective outpatient sex therapy treatment. Without deviations in family medical history, parents with university degrees, healthy, two-yearsyounger brother. He was treated six times in a psychiatric hospital for alcohol addiction and pathological gambling syndrome, first treatment occurred at the age of 28 . In the enforcement proceedings with a debt of CZK 500,000, which he increased during relapses. Completed his secondary education at high school with a school-leaving examination, higher education at Faculty of Mathematics and Physics at University of Technology unfinished, accepted to university five times in total. Currently unemployed, a year earlier he worked as a programmer. Single, childless, in a 7-year relationship with a partner who he met during one of the treatments, she suffers from social phobia. At present he has a 13-month love affair. First masturbation happened at the age of 13 with a fantasy of having sexual intercourse with his peers. First exhibition at the age of 16 in the windows facing the street, during which he masturbated in the expectation of being seen by the passers-by. First sexual intercourse at 24 years with a professional companion. Overall, at the time of the first visit to the sexologist, he had relationships with 3 women. He sees the main problem in alcohol. Currently, he is treated in a psychiatric hospital where he was ordered by the court into institutional protective sexology treatment, because during outpatient attendance he repeatedly exhibited his genitals during inebriety in the park. Due to the anxious-depressive symptomatology, antidepressant drug therapy has been deployed. In the expert opinion, he was assessed as having disorder - exhibitionism with sadomasochistic features and personality disorder. Serum testosterone control was performed and anti-androgens were deployed.

\section{Exhibitionism}

According to DSM-IV (1994), exhibitionism (302.4) is classified as one of the variations of sexual identity disorders. The patient experiences repeated intense sexually exciting behaviors and fantasies of exposing his genitals to someone unknown and unsuspecting. Behaviors and fantasies have to last for at least 6 months. They must also cause clinically significant problems or damage to the social or work life of the person or to other areas of his life.

The term comes from a Latin exhibere - to show, to offer. The excitement in exhibitionism is reached by exposing genitals to unknown girls or women. This exposure is sometimes connected with erection and masturbation (but not always). The exposure of the genitals can take place in front of a lonely woman or a group of women or girls (Weiss, 2002). The exposure to the groups happens almost always in front of young and children's objects. Most often, young women under 25 are attacked. Exposure in front of middle-age and elderly women is unusual and considered rather as "a mistake". Exhibition appears to be a seasonal phenomenon, which in not given biologically but climatically: more opportunities for exhibitionism are provided during the period from the late spring to early autumn, other months considering the low temperatures are not for exhibitionists convenient (Praško et al, 2011).

The term exhibitionism was introduced in 1877, when a French physician Ernest Charles Laségue defined it in an article entitled Les Exhibitionistes (The Exhibitionists). In his life's work called Sexual psychopathy from 1886, Richard von Krafft-Ebbing described exhibitionism as an offence against morals and violation of Article 516 of the Austrian Code of Laws.

Exhibitionism is one of the most common sexual deviations. It is highly compulsive in character, and therefore has a high and specific recidivism. In some exhibitionists, the needs of genital exposure appear at certain times, for example, during a period of psychic crisis or in situations of a partner conflict, but in the meantime, they do not urgently feel the compulsion to exhibit their genitals (Weiss, 2002). In others, however, this need is present permanently and is realized at least in the form of masturbation fantasies. During the subsequent masturbation in seclusion they imagine, for example, that the very same woman in front of whom they exhibited shows them her genitals (Kolářský, 2008). On top of that, it should be mentioned that it is necessary to distinguish exhibitionism from hypersexuality, 
which is an excessive sexual instinct (Nešpor, 2007). In exhibitionism, a mechanism of learning on predisposed terrain is presupposed. Cultural and educational influences also have a certain effect (Brtníková et al., 1989).

For example, psychoanalysis summarizes exhibitionism as a sexual perversion that serves as a statement of internal anxiety, usually associated with early childhood traumas, which functions as a defense against castration anxiety and as a means of enhancing masculine potency. It also protects the patient from homosexuality and sexual intercourse with women, which could be perceived as dangerous and castrational (Kennedy, 2001).

If the perpetrator of the exposure is caught, according to Czech legislation he can be accused and prosecuted for the offence of disorderly conduct under Paragraph 202 of the Criminal Code with imprisonment of up to two years. In case of exhibitionism, however, the criminal charges are generally low (Janula, 2000). Latent criminality is in this delinquency high: according to Cox and Maletzky (1980), only $17 \%$ of exhibitions are reported.

A true exhibitionist is paradoxically, in most of the cases, timid and shy man, often socially well adapted and in a well-adapted relationship. He usually does not establish any contact with his objects; he does not communicate with them and keeps a certain distance from them. At best, he draws attention to himself by whistling, coughing, etc. To become sexually excited, a glance from a passing woman or a girl - the notion that he, or rather his penis, was seen - is stimulating enough. The exhibitionist does not realize (or admit) that his object is not erotically tuned, that the woman or girl does not care for the look at his erect member, and that by exhibiting he intrudes into the victim's territory and violates her intimate sphere. Sometimes he exhibits his genitals in the state of extreme narrowing of consciousness: his attention is narrowed only to the act of exhibition. Sometimes he also expects some form of "counterexhibition" from his object. He often lives in the illusion that women like his behavior and even that his behavior sexually excites them. The exhibition contains some kind of unconscious wish after a positive reaction of the object. The exhibitionist wants the girl or woman to look at him curiously and with fascination. If this expected reaction is absent or altogether disapproving (women when seeing an exhibitionist often react with screaming, horror, indignation, fear of possible aggression, or even with compassion and contempt), the feeling of psychic tension usually disappears and only the feeling of shame remains (Weiss, 2002).

Kolářský and Madlafousek (1980), who consider exhibitionism to be a disorder of the initial stages of the sexual motivation system, emphasize the fact that exhibitionists avoid their own sexual partners while choosing an object of their exhibition, and at the same time, they avoid friendly erotic communication of the victim. The exhibitionist, therefore, avoids the erotic stimuli during the introductory phases, although elsewhere he is sexually excited by them. The anti-erotic emotions of a woman (fear, anger, disgust, etc.), who sometimes provokes the exhibition, do not excite him at all (Weiss, 2002).

If the woman indicates her interest in closer contact (verbally or by approaching the exhibitionist), the real exhibitionist actually, in most of the cases, ends the exhibition and leaves the place. If he does not receive the preferred reaction from the subject, the exhibitionist tends to repeat the exhibition in front of other women until he reaches his satisfaction. Before the exhibition he usually experiences a state of excited expectation, restlessness, compulsion, excitement, and then, after the exhibition, a temporary relief, which is often followed by feelings of shame and guilt, sobriety and awareness of the absurdity of his behavior (Weiss, 2002).

The exhibition sometimes happens without an erection - just in a form of presentation of a flaccid penis - but it is usually connected with erection and possibly even with masturbation. The orgasm occurs during this activity or, subsequently, with the image of the exhibition he just experienced. The exhibitionists usually choose lonely places (parks, walkways, etc.) for the exhibition. Sometimes, despite the real danger of being caught, they expose themselves, for example, in front of their apartment window or in the car. Apart from the possible exciting effect that the possibility of being revealed and captured poses for some of them, the compulsivity of exhibitionistic needs and the inability of a volitional coping can play a significant role in these cases. Most exhibitions take place in daylight (MacDonald, 1973), most often between 8-9 am and 3-5 pm, mostly from Friday to Sunday evening (the most number of sexual offenses are committed during this period in general).

Most exhibitionists are represented by young men aged 30-40 (Zvěřina et $\mathrm{al}, 1985)$. According to Zvěřina (1990), for offenses associated with high sexual activity, the principle that the perpetrator's danger decreases significantly after the $35^{\text {th }}$ year of his life applies here. Among the exhibitionists there are the most intellectually gifted individuals (Weiss, Brichcín, 1991). Despite the large number of researches that focus on identifying personality characteristics of exhibitionists, there is no evidence that would suggest the possibility of creating a specific psychological profile for these individuals. Even though they are characterized as introvert, shy, timid, internally insecure, socio-sexually retarded men (Zvěřina, 1980), many researches indicate that some of them are sthenic and extrovert individuals with higher aggressiveness. For example, in their group of exhibitionists examined by Cattel's 16 PF Questionnaire, Zvěřina et al. (1986) found that $41 \%$ of respondents have personality abnormality in terms of inhibitions and autism. Up to $31 \%$, however, have explosive and aggressive features. According to the results in Minnesota Multiphasic Personality Inventory (MMPI), exhibitionists most frequently have a profile indicating 
inhibitions, conformity and passivity (Forgac, Michaels, 1982), depression, alienation, insufficient strength of the ego and schizoid tendencies (Smukler, Schiebel, 1975). According to the findings of Hrnčírová et al. (1992), a problematic identification with father, characteristic introvertness, anxiety, neurotic personality traits and high discrepancy between the real and ideal self as a manifestation of insufficient self-acceptance can be found in this group of delinquents. In further research of Hrnčířová, Weiss and Brichcín (1992) on a group of 33 exhibitionists, up to half of them came from a disturbed family environment. The initial families of the patients appeared to be defective, particularly in terms of disruption of relationship between the parents, and the effectiveness or absence of father figure in upbringing. The occurrence of alcohol abuse was found in up to one third of the patients. Up to one fifth of the patients showed neurotic symptoms in childhood. In the personality structure, shyness, diffidence, vulnerability, hypersensitivity, tendency to worries and depressions, high levels of anxiety, feelings of guilt and isolation, and introvertness come to the fore.

The exhibitionists have a tendency to demean and underestimate their behavior, conceal the number of exhibitions, and find excuses (urinating in the park). They usually suspect or realize the presence of more serious disorders, and the probability of relapse is also high. Therefore, it is essential to set the intensive control regime with the necessity of demanding compliance with the agreed terms (dates, personal visit, consultation of the client's surroundings, client cooperation) and with the knowledge that most exhibitionists are actually ashamed of their behavior and consider it undignifying. An important risk factor is the client's potential feeling that "it will work out next time" and that "when they did not catch me, nothing happened" (Praško et al., 2011).

Data about the connection between exhibitionist activities and alcohol are not unified - numbers range from 16\% (Tabarka, Mikulík, 1980) to $51 \%$ of cases (Weiss et al., 1986). Basically, alcohol and other drugs can be considered as criminogenic factors disinhibiting the deviant predispositions that are present and weakening rational and free behavioral control. At the same time, alcohol consumption before committing a misdemeanor crime can also serve the offender as a rationalization of his deviant behavior. It is Křivák (1991) who mentions that exhibitionists often use the imperious urge to urinate as their camouflage or alibi, most often during an inebriety in which, according to the patients, they are literally deus ex machine disturbed by a passing woman. These men have the urge to so-called urination repeatedly on the places where women are present. However, the surprised women when presented with an exhibitionist "in action" and with a drunk, urinating man recognize the etogram of these two different behaviors accurately, quickly and almost infallibly.

Apart from alcohol and other drugs, other risk factors in terms of possible relapse appear to be stressful situations. The lapses of exhibitionists are also very frequent when they are, for example, under the influence of tiredness and sleeplessness after returning from night shifts, in the forced sexual abstinence or in situations such as work or family conflicts, deaths, etc. (Weiss, 2002).

According to Maletzky (1997), based on the exhibitionists' testimonies, we can talk about the basic points:

Exhibitionists in comparison to other offenders are most likely to underestimate the frequency of their delinquent activities.

Compared to other sex offenders, they are less likely to treat their behavior as threatening or harmful to the subject.

Compared to other offenders, they are more likely to deny the coexistence of other deviations.

Compared to other offenders, they are more likely to have higher incidence of sexual offences of other than exhibitionistic character.

However, not everyone who exposes his genitals is a true exhibitionist. If a man shortens the distance between him and the women, establishes with them mostly vulgar communication, wants to raise fright and fear in them, or seeks physical contact directly, he is likely to be an exhibitionist, sexual aggressor or sadist. In these cases, there is always a risk of escalating the aggression when repeating the offenses (Weiss, 2002).

The connection between exhibitionistic and other deviant activities is proven, for example, by the data from Freund (1990), who in the anamnesis of his group of 241 exhibitionists found voyeuristic actions in 32\%, toucheristic or frotteuristic acts in 30\%, and sexually aggressive actions in $15 \%$. From the psychopathological point of view, exhibitionism is most often associated with personality disorders (see the initial case report) (Weiss, 2002).

\section{Therapy of Exhibitionism}

Exhibitionist is considered to be an ideal client of individual, couple's and even group psychotherapy. But the psychotherapy is a long-term work, linked to occasional failure (compulsive component is very imperative and poorly manageable for the client) (Praško et al., 2011).

In pharmacological treatment, suppression of androgens and use of antidepressants are considered to be effective. Androgen suppression should be indicated based on knowledge of levels of testosterone and free testosterone in the serum. Very common is also application of SSRI-antidepressants that should get the emotional side of a client under control, especially his dealing with the fact that his "satisfactory sexuality is deviant" (Praško et al., 2011). Wolfe (1989) reports a $15 \%$ relapse rate in exhibitionists. According to Maletzky (1997), relapse after treatment with anti-androgens is low, but soon after drug discontinuation it increases significantly. 
Therefore, it is advisable to combine pharmacotherapy with cognitive behavioral psychotherapeutic procedures.

Most exhibitionists get to the sexology clinic as a result of the court-ordered outpatient sex therapy treatment. Clients themselves tend to underestimate the seriousness of their behavior ("it's no big deal", "no one was harmed", "if she didn't want to see it, then she shouldn't have looked"), they deliberately mislead the frequency of exhibitions ("the cops are totally crazy, I would never show my penis...", “...once or twice at most"), and they do not understand the criminogenic component of their behavior ("So what? Every one of them has already seen a great deal of weeners in her life anyway!") (Praško et al., 2011). Since the treatment is often ordered by the court, patients' attitude to it is also very indifferent. Doing something that a person has not voluntarily decided for is often a stumbling block in the initial phase of the treatment process. Frequently, the therapist encounters unmotivated, negative, passive- (and sometimes even active-) aggressive patients who reject treatment. In the protective treatment, we encounter a high level of involuntariness in combination with low motivation (Bošiaková, 2013).

Usually, the individual and group cognitive behavioral psychotherapy is combined. When combined with hormonal therapy, it has better results as far as relapses are concerned. Therapy has these goals:

To control paraphilic fantasies and behavior with the aim to reduce risk of relapse.

To control the sexual drive and reduce patient's distress (Zvěřina, 2012).

In other words: "The long-term goal of the treatment is therefore a non-delinquent behavior of the client in the future, his satisfactory sexuality and maintaining a relationship“ (Praško et al., 2011, p. 459).

\section{Individual Therapy}

The goal of individual therapy is to explain the nature of his sexual disorder to the client:

To explain the reason why this disorder is regarded as a behavior in violation of the law

To educate the client the principles of substitute behavior and seek an acceptable solution for his sexuality.

To build a relationship of trust in which the client opens completely and allows the therapist to look for the reason why is exhibition so crucial and motivating for the client.

To explain the view of the family, and social deprivations in case the objects that were exposed to the exhibitions are revealed (Praško et al., 2011).

\section{Couple's Therapy}

The goal of couple's therapy is to find a dysfunction in the pair sexuality. An integral part of cognitive behavioral therapeutic work is to teach a patient to take responsibility for the relations he creates and for the way he experiences his life. It is important to find ways to eliminate or minimize this dysfunction. It is also necessary to explain to the patient's partner the problems of exposition and her possibilities in the deviant's life; subsequently, the partner can fill a role of "external controller" (the field for exhibition will be narrowed, her control over taking the medication etc.) (Praško et al., 2011). Weiss and Zimanová (1995) draw attention to the benefits of marriage and couple's therapy. It can give the women a chance for deeper understanding the problematic sexuality of their partners and to find more effective ways of preventing relapses. Although it is necessary to mention that the first reaction to inviting one's partner to the session is often rejection.

\section{Group Therapy}

The goal of group therapy is to enable the client to gain an insight and experience from other clients living with the same disorder and just like him seeking the way to non-delinquent sexuality. Getting the opinions and advice of the clients with the same disorder have different degree of seriousness than the therapists' procedures because the therapists "never exhibited and have nothing lose". It allows the therapist to minimize mistakes and modify the treatment procedures in confrontation with multiple views that can be a guarantee of objectivity (confrontation of theoretical knowledge with those who are actually experiencing the disease at various stages of development) (Praško et al., 2011). The group has usually 6 -12 members. The ideal number is 8 . The length of one session is approximately 1,5-2 hours (Praško, 2007).

\section{Cognitive Behavioral Therapy of Exhibitionism}

Many patients are willing to trust only the therapist about whom they are convinced that he is fair, honest, sincere, selfless, and he perceives helping people as a mission. Without this idealization they would probably not have begun to function with him therapeutically. If the psychotherapist fails in one of these characteristics, the psychotherapeutic relationship is impaired (Vyskočilová, 2015).

The goals of individual and group cognitive behavioral psychotherapy are basically identical with those mentioned in the previous chapter - gaining insight, increasing personal responsibility and competence of the patient, and changing his sexually nonconforming behavior.

Zimanová et al. (1986) states that the groups should be led by a male and female therapist. Harrisová (1996) described the specifics of the female role in the context of CBT. According to her observation, 
the group dynamics towards a male therapist is - from the patients' side - based on conflict and competition while towards a female therapist it lies more in control and politeness. Zimanová et al. (1986) further suggests that a male therapist should try to take rational and unambiguous attitudes while the female therapist should provide emotional support and take rather protective attitude. The indisputable advantage of group therapy is the fact that it facilitates familiarization of people with similar fates and in similar life situation. The group cancels the current isolation of paraphilic individuals and allows them to experience a feeling of belonging. It allows learning by imitation and understanding of one's issues. The group is able (more effectively that the therapist) to break the defensive mechanisms of the patient while providing a sense of emotional support and acceptance. And it also helps to reveal his dysfunctional rationalization (Weiss, 2002).

An essential condition for successful therapy is basic adaptation of the patients' behavior in the broadest sense. Within this process, frequent complication of the institutional protective treatment is their social maladaptation after serving a sentence including dysfunctional behavioral standards transmitted from the prison subculture. The most common secondary diagnosis is a personality disorder with features of non-restraint and dissocial behavior. The situation is often complicated by alcohol or drug abuse. For basic adaptation of behavior, the community system of departments based on a consistent regimen effect on a patient with a fixed daily order and clear behavioral system of rewards and punishments appears to be the most effective (Weiss, 2002).

Obtaining adequate information on normal and deviant sexuality allows patients to better understand their own symptoms of abnormal psychosexual development; it gives them the opportunity to classify their own paraphilic behavior within a wider theoretical framework; it also makes it easier for them to verbalize problems in this area. According to Trojan et al. (1990), this is actually a correction of the cognitive framework.

During their life, patients usually create whole system of defense regarding their deviant sexual behavior. They tend to blame others as well as themselves for their problems and they usually do not take responsibility for their behavior. Overcoming these defense mechanisms, therefore creating a critical view of their own paraphilic motivations and deviant behavior, appears to be a prerequisite for successful psychotherapy. Typical examples of defensive reactions of compromise character in exhibitionists are rationalization and intellectualization. These can be very primitive, for example, presentation of exhibition as urination, but also very sophisticated such as exhibition as an artistic performance (Weiss, 2002).

Apart from the defensive mechanisms, the psychotherapeutic process is usually hindered by the deviants' lack of motivation for treatment. Their attitudes to treatment are ambivalent because the treatment actually deprives them of the preferred way of sexual satisfaction. The patients should develop a more symmetrical and pro -social attitude towards their surroundings during the treatment (Weiss, 2002).

It is necessary to find alternative ways of socially acceptable sexual satisfaction as an essential factor in successful adaptation. According to Zimanová and Hubálka (1983), the adaptation goals are as follows:

Adaptation to heterosexual coital activities with an adult woman.

Adaptation to heterosexual non-coital activities with an adult woman. Adaptation to autoerotic masturbation activities.

Adaptation to deviant but socially acceptable forms of sexual behavior (e.g., BDSM clubs)

Temporary (pharmacological) or permanent (surgical) alleviation of sexual needs.

\section{Correction of Cognitive Distortion}

During their deviant careers, most deviants create many false assumptions and rationalizations regarding their sexual behavior. This way they can avoid even negative emotions and thinking about the consequences of their actions. The most common manifestations of this cognitive deconstructionism are denial, minimization, accusation of the victims, lack of social competence and alcohol and drug problems. Maletzky (1997) categorizes these mechanisms:

Transferring the guilt ("The way she was dressed she expressly asked for that.")

Denial of sexual motif ("I was just looking for a place to urinate.")

Impeaching a witness ("She has always lied.")

Minimizing the consequences ("She was smiling, so she had to like what she saw.")

Rejection of criticism ('It's not the same. It's not like I raped someone.")

Excusing the causes ("If my partner met my sexual needs, I would not have to do that this way.")

Exhibitionists sometimes claim that they actually provide sexual education or encouragement to the women in front of whom they exhibit. Identification of these mechanisms is the first step of treatment with the help of therapist. It is important for the patient to understand what significance the rationalizations have in promoting his own deviant behavior. Then, on a conscious level he should build up a certain correction principles with whom he then automatically associates his thoughts in risk situations (instead of "she smiled, so she liked it," the first thought that comes up should be "many women are in these situations confused and they do not know how to react; however, this does not exclude the possibility that she is feeling unpleasantly" (Weiss, 2002). 


\section{Relapse prevention}

It is based on the premise of successions and cycles in which the sexual offense is the culmination and result of chain of seemingly insignificant events. The patient's first task is to compile a record of his failures, including the events that led to them, and a list of possible insurances that could serve as brakes for further follow-up attacks. At the same time, he is asked to identify the situations that specifically represent a risk of relapse. The next step is to create control mechanisms (exhibitionist who repeatedly exhibited his genitals when walking a dog asks his partner or family member for accompaniment) Patient should then practice these alternative strategies in real life; he should also update and internalize them sufficiently. External control from family members or colleagues from work can also play a major role. Mental control method (stress or anger management strategy) to be able to replace deviant fantasies with normal sexual or non-sexual images in risky situations is also a good strategy (Johnston, 1997).

\section{Empathy Training}

Many of the sexual deviants are not able to empathize with the feelings of the victims, nor are they able to estimate the possible consequences of the crime for their life and future. Empathy training can be divided into 5 phases (Maletzky, 1997):

Identification of the victim

Identification of the victimization act

Identification of the damage

Role reversal

Empathy development

In the first step, the therapist should provide the possibility to confront the victim's feelings, for example, by reading testimonies. Within the second phase, these activities should lead to an accurate discrimination of those aspects of the patient's behavior that represent their own deviant offence. In the third phase, the patient should be informed about the consequences of the experienced events on the mental and physical health of the victim; he should then conclude that the described traumas are direct consequences of his deviant behavior. Then, reversal of roles in the form of, for example, psychodrama where he can be questioned about the victim's feeling during and after the crime, follows. All these activities should in the last phase lead to the patient's ability to empathize with the victim and to realization that his behavior is harming other people. The ability to empathize with the victim is the basis for a real change in the patient's behavior and the prevention of relapse (Weiss, 2002).

\section{Intimacy Training}

Sexual offenders are believed to also have deficits in the area of intimacy. The results of these deficits are the feeling of loneliness, the limitation of social contacts and the absence of relationships. They have dysfunctional ways (such as anxious, ambivalent or rejective) of establishing emotional ties. This dysfunction can be caused, for example, by their fear of rejection. Therefore, the training of social skills is important. Verhagen (1999) describes experiments with intimacy training at two Dutch clinics. Patients established intimate contact with a "proxy" partner, so-called intimacy coach. During 10 to 15 sessions (in which both of them were naked) they played sexual games. Coitus was not allowed. The training results could be summarized as improvement of skills in the area of relationship, empathy and self-confidence enhancement. I am not convinced that this type of training would be possible in the conditions of the Czech healthcare - either because of the absence of trained intimacy coaches or due to exorbitant financial payments that would not be paid by the insurance companies, and, last but not least, due to the typical Czech narrow-mindedness.

\section{Self-confidence Training}

Strengthening of self-confidence influences the strength and duration of the therapeutic effect more than just mere focusing on the problematic behavior. Negative self-conception may be an obstacle to effective treatment, and low self-esteem also conditions nonemphatic attitudes towards victims, socially inappropriate behavioral patterns, and lack of skills necessary for intimate relationships. According to Marshall (1996), negative self-conception can also correlate with sexual anxiety, aggression, non-assertiveness, and even with deviant sexual preferences. In the exhibitionism treatment, emotional fluctuations can be expected because the patients are during their therapy confronted with their difficult situation and unpleasant experiences from the past.

\section{Overcoming Resistance}

Several cognitive behavioral techniques are used to overcome the resistance, namely:

Psychoeducation

Assessment of consequences

Positive re-labeling

Using analogies and metaphors

Paradoxical intervention - it involves giving absurd encouragement to the patient to continue his deviant behavior for which he was convicted until he realizes the senselessness of his actions (Weiss, 2002).

\section{Conclusion - Practical Demonstration}

Patient 0. T. was assigned to a psychotherapeutic group of exhibitionists and stalkers; concurrently, individual psychotherapy took place. He voluntarily participated in an optional ergotherapeutic group that took place twice a week. In the first months of the treatment, he carefully, even in perfectionist way, elaborated his personal CV and vita sexualis, he was educated in sexually paraphilic 
issues, and thereby he gained awareness of his socially intolerable behavior. As a part of individual therapy, he worked on the identification of risk factors and relapse triggers. Although he initially designated alcohol and winning on gambling machines as the main triggers, during therapy he found out that the main causes of sexually deviant behavior were fatigue and stress resulting from dissatisfaction with his socio-economic situation. Dysfunctional thinking schemes and cognitive mistakes were identified ("I haven't achieved anything in my life", "I am completely useless") and cognitive restructuring was initiated. The patient continuously practiced autogenic training, calming abdominal breathing, imagination of "Safe and secure place", and began to attend hiporehabilitation. As a part of the empathy training, he wrote a "Letter to the Victim" and "Victim's Letter to the Offender" for the group psychotherapy sessions, which the group accepted very positively.

After 3 months of hospitalization, the doctor advises to use antiandrogens; the patient is defiant, he disagrees with this type of pharmacotherapy, he perceives it as a punishment, an assault on his masculinity and sexual performance, "you want to take away from me the last pleasure that is left in my life", he is sarcastic, starts using vulgarisms when in contact with staff and patients. At both group and individual sessions, he repeats without explanation the phrase that he "wants less treatment and more punishment", which he explains on the third group session after anti-androgens deployment. He would rather go to prison and complete his sentence there then being hospitalized in a psychiatric hospital, although he is not able to rationally explain the reasons for these statements. Patient in strong resistance, we use paradoxical interventions during which, together with the patients who had already been arrested and completed their sentence in prison, we illustrate the absurdity of the patient's attitude. Patient is strongly distraught; he is sweating, gets red in his face, and then he exclaims disgruntledly that "prison would finally make a man out of me" and leaves the session in tears.

In the following days, we reflect what happened on the group session and patient's behavior in recent weeks. The patient is cooperating, he agrees with anti-androgens deployment, recognizes the inappropriateness and absurdity of his behavior, spontaneously starts to look for alternatives for partners' sexual life under hormonal attenuation; he wants to further participate in treatment. We also work on self-confidence training, patient starts jogging and goes to gym every day, he tries to improve his appearance, gain muscle mass; he is supported in recognition of his positive qualities in the form of personal affirmations (e.g. "I am nice and good person"); his unofficial girlfriend is also involved: she wrote down a list of character traits she appreciates in him and that attract her to him, and which the patient always wears with himself. In his hospital ward, he is a valid member of patient co-management; he provides quality feedback to the others in the group sessions, and prefers a community-based approach; he goes to several-day vacation, returns in good shape, and does not relapse with alcohol, gambling or exhibitions.

As a part of relapse prevention we work on the systematization and consolidation of social ties; after 6 months of treatment the patient decides to end his concurrent partner relationships. After 7 years he breaks up with his official partner. He considers this former relationship he as dysfunctional, moves his personal belongings from the common household to his parents' and he makes his other girlfriend an official partner with whom he plans the future together. From his disability pension he is repaying debts and executions, looks for a permanent job with fixed working hours, and renews relationships with his parents and brother. He found and internalized alternative adaptation methods of sexual satisfaction (so-called "adaptive goals") in the form of coital and non-coital activities with his partner, masturbation, or erotic "tantra" massage salons visits. After 8 months the therapy is discontinued and the patient undergoes the planned protective institutional alcohol treatment; he feels good, cooperates, has a well-formed view of his own paraphilic sexuality and wants to continue working on himself.

\section{BIBLIOGRAPHY}

AMERICAN PSYCHIATRIC ASSOCIATION (1994). Diagnostic and Statistical Manual of Mental Disorders. Washington, D.C.: American Psychiatric Association.

BOŠIAKOVÁ, L. (2013). Motivování pacientů na ochranné protitoxikomanické léčbě prostřednictvím KBT. Alkoholismus a drogové závislosti (Protialkoholický obzor). 48 (5), 219-227.

BRTNÍKOVÁ, M., et al. (1989). Sex? AIDS! Praha: Horizont.

COX, D.J., \& MALETZKY, B.M. (1980). Victims of exhibitionism. In Exhibitionism. New York: Garland.

FORGAC, G.F., \& MICHAELS, E.J. (1982). Personality characteristics of two type of male exhibitionists. J.Abnorm.Psychol. 91, 287-293.

FREUND, K. (1990). Courtship disorders. In Handbook of sexual assault. New York: Plenum Press.

HARRIS, P.J. (1998). The role of the female therapist in the treatment of child sex offenders. V.International Conference on the Treatment of Sexual Ofenders in Caracas.

HRNČÍŘOVÁ, A., WEISS, P., \& BRICHCÍN, S. (1992). Příspěvek k sociokulturní a psychologické charakteristice hospitalizovaných exhibicionistů. Československá psychologie. 37 (3), 236-246. 
JANULA, J. (2000). Diagnóza: Deviant. Praha: Alberta Plus.

JONSTON, L., WARD, T., \& HUDSON, S.M. (1997). Deviant sexual thoughts: Mental control and the treatment of sex offenders. J. Sex. Res. 34, 121-130.

KENNEDY, R., ABEL-HIRSCH, N., PAJACZKOWSKA, C., \& KAHR, B. (2002). Témata psychoanalýzy II. Praha: Portál.

KOLÁŘSKÝ, A. (2008). Jak porozumět sexuálním deviacím. Praha: Galén.

KOLÁŘSKÝ, A., \& MADLAFOUSEK, J. (1980). Vzrušuje exhibicionisty strach či hněv žen? Čas. Lék. Čes. 119, 17-18.

KRAFFT-EBING, R. (1886). Psychopathia sexualis: mit besonderer Berücksichtigung der conträren Sexualempfindung. Eine medizinisch-gerichtliche Studie für Ärzte und Juristen. Stuttgart: F.Enke.

KŘIVÁK, F. (1991) Opilost jako alibi a kamufláž (Mikční etogram mužů ve vztahu k ebrietě a k exhibicionismu. Protialkoholický obzor. 26 (3), 391-396.

LASÉGUE, E.C. (1877). Les Exhibitionistes. In L'Union Médicale. 23, 709-714

MACDONALD, M.J. (1973). Indecent Exposure. Springfield: Charles C. Thomas.

MALETZKY, B.M. (1997). Exhibitionism: Assessment and treatment. In Sexual deviance: Theory, assessment, and treatment. New York: The Guilford Press.

MARSHALL, W.L. (1996). The relationship between self-esteem and deviant sexual arousal in non-familial child molesters. Behav. Modif. 21, 86-96.

NEŠPOR, K. (2007). Návykové chování a závislost. Praha: Portál.

PRAŠKO, J., et al. (2007). Kognitivně behaviorální terapie psychických poruch. Praha: Triton.

PRAŠKO, J., LÁTALOVÁ, K., TICHÁČKOVÁ, A., \& STÁRKOVÁ, L. (2011). Klinická psychiatrie. Praha: Tigis.

SMUKLER, A.J., \& SCHIEBEL, D. (1975). Personality characteristic of exhibitionists. Dis.Nerv.Sys. 36, 600-603.
TABARKA, K., \& MIKULÍK, J. (1980). Podrobná analýza charakteristik delikventních exhibicionistů v Severomoravském kraji v letech 1974-1977. Čas.Lék.čes. 119, 500-503.

TROJAN, O., WEISS, P., \& BRICHCÍN, S. (1990). Poznámky k ochranné léčbě sexuálních delikventů. Čs.Krimin. 23, 124-129.

VERHAGEN, T. (1999). Intimacy training in the Pompekliniek and Hoeve Boschoord, The Netherlands. II. East-West Conference on Child Sexual Abuse and Sexual Violence in Prague.

VYSKOČILOVÁ, J., et al. (2015). Svoboda a psychoterapie. Psychiatrie pro praxi. 16 (3), 108-114.

WEISS, P. (2002). Sexuální deviace. Praha: Portál.

WEISS, P., \& BRICHCÍN, S. (1991). Inteligence sexuálních deviantů. Československá psychologie. 35 (5), 419-423.

WEISS, P., \& ZIMANOVÁ, J. (1995). Partner relations of sex offenders. Rev. Sexolog. 1, 7-10.

WEISS, P., et al. (1986). Některé sociokulturní rozdíly mezi pachateli sexuálních deliktů. Čs.Psychiat. 82, 228-232.

WOLFE, R. (1989). Novel techniques in treating the sexual offenders. Annual Conference of ATSA in Seattle.

ZIMANOVÁ, J., \& HUBÁLEK, S. (1983). Devianz im Griff. Sexualmedizin. $12,383-386$.

ZIMANOVÁ, J., WEISS, P., \& FUKA, J. (1986). Psychoterapie v ústavní léčbě sexuálních delikventů. Čas.Lék.čes. 125, 744-746.

ZVĚŘINA, J. (1980). Obnažování pohlavních orgánů na veřejnosti a exhibicionismus. Čs.kriminalistika. 13, 116-119.

ZVĚŘINA, J. (1990). Sexuální deviace - vztah k sexuální delikvenci. Kriminal. Sborník. 1, 36-38.

ZVĚŘINA, J. (2012). Terapie sexuálních deviantů - mezinárodní standardy. Česká a Slovenská psychiatrie. 108 (1), 35-40.

ZVĚǨINA, J., et al. (1985). Některé charakteristiky souboru 288 expozérů genitálu. Čs.kriminalistika. 18, 258-261.

ZVĚǨINA, J., et al. (1986). Osobnost exhibicionistů v šestnáctifaktorovém osobnostním dotazníku. Čas. Lék. Čes. 119, 504-506.

PhDr. Jan Jokl

Kosmonosy Psychiatric Hospital, Department of Sexology jokljan@email.cz 